\title{
Influence of drying process on total phenolics, antioxidative activity and selected physical properties of edible bolete (Phlebopus colossus (R. Heim) Singer) and changes during storage
}

\author{
Wijitra LIAOTRAKOON ${ }^{1 *}$, Vachiraya LIAOTRAKOON ${ }^{1}$
}

\begin{abstract}
The research aimed to study the effect of hot-air drying on the properties of edible bolete mushroom (Phlebopus colossus (R. Heim) Singer). Fresh edible bolete contained an efficient antioxidant activity, showing a significant value of total phenolic content and radical scavenging activity and was high in protein and fiber with low fat content. The changes in physicochemical and antioxidative properties of edible bolete during hot-air drying at various temperature and time were studied. The phenolic content and antioxidative properties of edible bolete decreased with the temperature and drying time. At $60{ }^{\circ} \mathrm{C}$ for $5 \mathrm{~h}$, the phenolic content and antioxidative properties of the dried edible bolete remained at $25 \%$ compared to the fresh mushroom. Moreover, there was no substantive change in the bacterial count of dried edible bolete with vacuum packing after six months at room temperature.
\end{abstract}

Keywords: hot-air drying; edible bolete; physicochemical properties; antioxidative activity.

Practical Application: The dried edible bolete presented as a sufficient source of natural antioxidants. This study has significant importance for further developing the products related to edible bolete.

\section{Introduction}

Mushrooms are a large group of macroscopic fungi and important sources of protein. Wild edible mushrooms are also grown and their consumption has continually been increased, particularly wild boletes. Boletes are freshly pored mushroom which belong to Boletales. This order includes some gilled mushrooms in the families Gomphidiaceae and Paxillaceae, which have the same flesh texture and similar micromorphological and molecular phylogenetic characteristic (Hawksworth et al., 1995). In Thailand, wild boletes are classified into 9 species. Among these species, Phlebopus colossus (R. Heim) Singer (or Boletus colossus Heim.) is the most common Thai wild boletes found in the country. This edible bolete is also known as Tab Tao mushroom, Tab Tao Dam mushroom, Nam Phung mushroom or Har mushroom. The external color is black with the yellow interior. Edible bolete is occasionally found during the raining season each year and also reported as mycorrhizal fungus with several species of host trees. Moreover, it is the most commonly found in large number and sold in local markets of Thailand (Seehanan \& Petcharat, 2008).

The antioxidant compounds, such as phenolic compounds, tocopherols, ascorbic acid, and carotenoids, from wild mushrooms have been identified. These mushrooms might be used for diet as health food, and taking advantage of the additive and synergistic effects of all the bioactive compounds present to against oxidative processes as natural potential antioxidants (Ferreira et al., 2009; Rai et al., 2005). The extracts of Boletus edulis, which is a well-known European bolete, have a high content of phenolic compounds and reducing power than that of Agaricus bisporus, Coprinus comatus, Pleurotus eryngii and P. ostreatus (Tsai et al., 2007). Positive correlations were found between total phenolic content and antioxidant activities in the extracts from Shiitake mushroom and straw mushroom (Volvariella volvacea) (Cheung et al., 2003). Moreover, it was reported that the cooking by boiling, microwave heating and steaming affected the amount of antioxidants and phenolic compounds in various vegetables (Turkmen et al., 2005).

As mushrooms are rapidly perishable food, they start deteriorating immediately after the harvest. In view of their highly perishable nature, the fresh mushrooms have to be processed to extend their shelf life for the off-season use. Mushrooms can be processed in many other ways to extend their shelf life such as drying, which is a comparatively low-cost method, pickling, and canning. The factors that affect the drying rate are drying temperature, pre-drying treatments, thickness of mushroom, method of drying and moisture diffusivity (Yapar et al., 1990). The drying time for drying button mushrooms (Agaricus bisporus) and oyster mushrooms ( $P$. flavus) with a vacuum dryer was the longest among drying with a cabinet dryer, a fluidized bed dryer and a microwave oven. The fluidized bed drying provides good quality products (Walde et al., 2006). However, a cabinet dryer, which is a convectional drying method, seems to be an alternative method for drying mushrooms because the method is simple and inexpensive. 
This study reports the nutritional value and antioxidative properties of untreated edible bolete compared to others exotic mushroom varieties, i.e. Shiitake (Lentinus edodes (Berk.) Singer), Eryngii (P. eryngii) and oyster mushrooms (P. sajor-caju). Hence, the changes in physicochemical and antioxidative properties of edible bolete during the hot-air drying at various drying temperature and time, and the changes of properties over six months of dried edible bolete with and without vacuum packing were also monitored.

\section{Materials and methods}

\subsection{Preparation of fresh mushrooms}

Fresh edible bolete (Phlebopus colossus (R. Heim) Singer or Boletus colossus Heim.), Shiitake, Eryngii and oyster mushrooms were collected from Thai local market. They were cleaned to remove adhering extraneous matter, cut, washed thoroughly in running water and allowed to drain in order to get an edible sample. After that, their chemical properties, phenolic content and antioxidant activity were determined.

\subsection{Preparation of dried edible bolete}

Aforementioned edible bolete was sliced into pieces of about $5 \mathrm{~mm}$, placed on the trays and dehydrated in a drying oven (model FD 115, Binder, Germany) at 40,50 and $60^{\circ} \mathrm{C}$ for $5 \mathrm{~h}$ (interval $1 \mathrm{~h}$ ). The dried mushroom was sampling every hour over a studied period to determine the water activity $\left(A_{w}\right)$, color parameters, rehydration ratio, phenolic content, and antioxidant activity.

\subsection{Determination of physicochemical properties}

The values of $\mathrm{A}_{\mathrm{w}} \mathrm{pH}$, moisture, protein, fat, fiber, and ash contents of edible bolete were examined according to standard methods, as described by AOAC (Association of Official Analytical Chemists, 1995). The carbohydrate content was determined as the difference between 100 and the sum of the percentages of moisture, protein, fat, fiber, and ash. Besides, the Hunter color parameters which referred to brightness $\left(L^{*}\right)$, redness-greenness $\left(a^{\star}\right)$ and yellowness-blueness $\left(b^{*}\right)$ values, of the mushroom sample were measured by a spectrophotometer (model UltraScan VIS, HunterLab, USA). To determine the rehydration ratio of the dried sample, $2 \mathrm{~g}$ of dried sample was soaked in $100 \mathrm{ml}$ of water at different temperatures $\left(25,55\right.$ and $\left.85^{\circ} \mathrm{C}\right)$ for a constant time of $30 \mathrm{~min}$. After rehydration, the excess water was drained. The samples were dried with absorbent papers and weighed for determination of the rehydration ratio by weight of dried sample before soaking divided by weight after soaking at various temperatures (modified from Apati et al., 2010). All measurements were performed in triplicate.

\subsection{Determination of antioxidative properties}

To extraction of polar compounds, $20 \mathrm{~g}$ of sample were extracted with $80 \mathrm{ml}$ of chilled $80 \%$ acetone solution in a blender for $10 \mathrm{~min}$. The slurry was vacuum-filtered and the extracts were stored in dark at $-18^{\circ} \mathrm{C}$ (modified from Mahattanatawee et al., 2006; Wu et al., 2006). The Folin-Ciocalteu's reagent was used for the total phenol content determination (Lim et al., 2007). The aliquot of $0.3 \mathrm{~mL}$ of extract was added to $1.5 \mathrm{~mL}$ of Folin-Ciocalteu's reagent (diluted 10 times with distilled water) and $1.2 \mathrm{ml}$ of $7.5 \%$ sodium carbonate. The samples stabilised after vortexing for $30 \mathrm{~min}$. The total phenol content was determined by using a spectrophotometer (model Libra S11, Biochrom, United Kingdom) at a wavelength of $765 \mathrm{~nm}$. The standard curve was prepared using solutions of gallic acid (GA) and then total phenol content was expressed as GA equivalents (in $\mathrm{mg} \mathrm{GA} / 100 \mathrm{~g}$ of sample). The DPPH radical scavenging activity assay was used to determine the radical scavenging capacity of the sample. One millilitre of the extract was mixed with $4 \mathrm{ml}$ of $80 \%$ ethanolic $0.6 \mathrm{mM}$ of 2,2-diphenyl-1-picrylhydrazyl (DPPH) solution. The absorbance was measured at $515 \mathrm{~nm}$ after standing for $3 \mathrm{~h}$ (modified from Wu et al., 2006). An $80 \%$ ethanol solution served as a blank. For this assay, solutions of GA were prepared for the standard curve, and the DPPH value was expressed in GA equivalents (in mg GA/100 g of sample). The determination of the total phenol content and antioxidant activity were performed in triplicate.

\subsection{Determination of microbiological properties}

The total plate count was obtained using the pour plate technique on plate count agar as standard methods agar (Association of Official Analytical Chemists, 1990). Duplicates were done for each dilution. The number of microorganisms was expressed as colony-forming units per $1 \mathrm{~g}$ of sample (CFU/g).

\subsection{Shelf-life study of dried edible bolete}

Dried edible bolete was packed with two packing methods, i.e. with and without vacuum packing in a polypropylene bag. Both samples were stored at room temperature $\left(35 \pm 2{ }^{\circ} \mathrm{C}\right)$ in a dark place for six months. The sample was taken each month to monitor the water activity $\left(\mathrm{A}_{\mathrm{w}}\right)$, moisture content, and the microbial count.

\subsection{Statistical analysis}

In the study, a completely randomized design was used as the experimental design. The data obtained from three replications were analyzed and shown as means+standard deviation (SD). The significant differences among means of all treatments were subjected to analysis of variance, and the confidence limits used in this study were based on $95 \%(\mathrm{p}<0.05)$.

\section{Results and discussion}

\subsection{Nutritional values and antioxidant activity of fresh mushrooms}

The study compared the nutritional value and antioxidant activity of edible bolete fruiting bodies with other three mushrooms, namely Shiitake, Eryngii and oyster mushrooms. The $\mathrm{pH}$ values of these untreated mushroom species were 4.41-6.58 and all studied mushrooms showed high $\mathrm{A}_{\mathrm{w}}$ and moisture content (0.993-0.997 and 85.5-93.1\%, respectively). The nutritional value of the untreated mushrooms is showed in Table 1 as dry weight basis. Bolete mushroom contained the highest protein, followed by Shiitake, Eryngii, and oyster mushrooms. 
The fat, ash and fiber contents of bolete mushroom were also statistically higher than the others $(\mathrm{p}<0.05)$. On the other hand, the carbohydrate of bolete mushroom had the lowest content $(\mathrm{p}<0.05)$. The protein content of B. colossus, which is known as Thai edible ectomycorrhizal mushroom, is similar to that of B. aestivalis (32.8\%) (Kumar et al., 2013) and B. griseipurpureus (31.4\%) (Aung-aud-chariya et al., 2012). Also, it is higher than some of Thai edible ectomycorrhizal fungi, such as Phaeogyroporus portentosus and Russula nigricans (22.6-24.2\%) (Sanmee et al., 2003). Therefore, B. colossus or Phlebopus colossus (R. Heim) Singer could be considered as an excellent source of protein.

The content of phenolic compounds in four species of mushrooms was in the range of 35.9-64.3 mg GA/100 g sample (as wet weight basis). The amount of phenolic compounds of edible bolete was the most significant content ( $64.3 \mathrm{mg} \mathrm{GA} / 100 \mathrm{~g}$ ) ( $\mathrm{p}<0.05$ ), followed by Shiitake (50.5 mg GA/100 g), oyster (38.7 mg GA/100 g) and Eryngii mushrooms (35.9 mg GA/100 g), respectively. In additions, the analysis of antioxidant activity by analyzing the ability to capture free radicals with DPPH showed that four mushroom species were in agreement with phenolic compounds in the analysis. The DPPH value of edible bolete was the highest content $(37.9 \mathrm{mg} \mathrm{GA} / 100 \mathrm{~g})(\mathrm{p}<0.05)$, followed by Shiitake (34.5 mg GA/100 g), oyster (11.4 mg GA/100 g) and Eryngii mushrooms (10.0 mg GA/100 g), respectively. In the study, the fruit bodies of edible bolete had a high antioxidant capacity as well as significant phenolic content and were rich in fibers and proteins, while it contained a low amount of fat. The results also suggested that the mushroom extract of edible bolete is a natural antioxidant resource. The results are consistent with the report by Vamanu \& Nita (2013), who found that B. edulis represents a natural source of functional compounds. According to Vidović et al. (2010), the main antioxidant compound, variegatic acid, had been detected in both boletus species (B. edulis and B. auranticus) and both extracts were indicated as good inhibitors for radical reduction and for scavenging that could help to prevent the oxidation. The methanolic extracts of B. edulis showed strong antioxidant activity patterns and excellent reducing powers (Sarikurkcu et al., 2008). Phenolic compounds, $\alpha$-tocopherol and $\beta$-carotene were also found in the methanolic extracts of dried B. badius (Elmastas et al., 2007). Currently, consumers are interested in healthy food or functional food, particularly with antioxidants such as phenolic compounds, phytonutrients and pigments, because free radicals give rise to many diseases. Antioxidants play an important role in preventing oxidation in the cell membrane by eliminating oxygen to prevent diseases (Ignat et al., 2011; Tesoriere et al., 2009; Maestri et al., 2006).

\subsection{Effect of hot-air drying on physical and antioxidative properties of dried edible bolete}

During drying, the $\mathrm{A}_{\mathrm{w}}$ and moisture content of the bolete mushroom were markedly decreased and after $5 \mathrm{~h}$ of drying at 40,50 and $60{ }^{\circ} \mathrm{C}$, these values decreased from 0.997 to $0.887,0.864$ and 0.636 , and from $93.1 \%$ to $63.4 \%, 55.7 \%$ and $14.2 \%$, respectively. These values of dried edible bolete at $60{ }^{\circ} \mathrm{C}$ were the lowest among those of the mushroom at the other drying temperatures. The drying curve of edible bolete is illustrated in Figure 1 and the drying rates of edible bolete at 40,50 and $60^{\circ} \mathrm{C}$ were $0.77,1.03$ and $2.25 \mathrm{~g}$ of moisture/ min, respectively. The drying rate was increasingly high at a high temperature of drying, showing decreased in moisture content of the dried bolete. The result is in agreement with the result found for P. ostreatus drying (Apati et al., 2010). Hence, the rehydration rate at 25,55 and $85^{\circ} \mathrm{C}$ of the dried edible bolete at $60^{\circ} \mathrm{C}$ for $5 \mathrm{~h}$ was $2.1,2.5$ and 2.9 times, respectively. The dried mushroom might absorbed more water at a higher temperature compared to that at low temperature. This is consistent with the report by García-Pascual et al. (2005) on the rehydration of air-dried B. edulis.
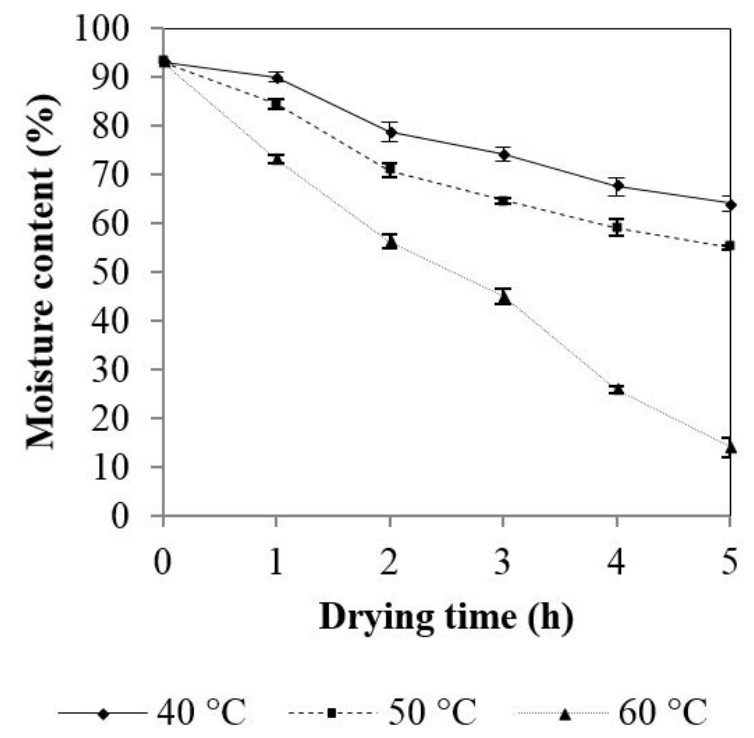

Figure 1. Drying curve of edible bolete at various temperatures for $5 \mathrm{~h}$.

Table 1. Nutritional values on dry weight basis of different mushroom species.

\begin{tabular}{crrrr}
\hline \multirow{2}{*}{ Characteristics } & \multicolumn{3}{c}{ Mushroom species } \\
\cline { 2 - 5 } & Bolete & Shiitake & \multicolumn{1}{c}{ Eryngii } & Oyster \\
\hline Protein (\%) & $37.7 \pm 0.2^{\mathrm{a}}$ & $33.1 \pm 0.2^{\mathrm{b}}$ & $30.2 \pm 0.2^{\mathrm{c}}$ & $23.7 \pm 0.1^{\mathrm{d}}$ \\
Fat (\%) & $1.4 \pm 0.0^{\mathrm{a}}$ & $0.7 \pm 0.0^{\mathrm{c}}$ & $0.2 \pm 0.0^{\mathrm{d}}$ & $0.9 \pm 0.0^{\mathrm{b}}$ \\
Ash (\%) & $10.1 \pm 0.0^{\mathrm{a}}$ & $8.3 \pm 0.0^{\mathrm{b}}$ & $8.3 \pm 0.0^{\mathrm{b}}$ & $7.9 \pm 0.0^{\mathrm{c}}$ \\
Fiber (\%) & $5.8 \pm 0.1^{\mathrm{a}}$ & $4.1 \pm 0.0^{\mathrm{b}}$ & $1.9 \pm 0.0^{\mathrm{c}}$ & $1.8 \pm 0.0^{\mathrm{c}}$ \\
Carbohydrate (\%) & $44.9 \pm 0.1^{\mathrm{d}}$ & $53.8 \pm 0.2^{\mathrm{c}}$ & $59.4 \pm 0.2^{\mathrm{b}}$ & $65.8 \pm 0.2^{\mathrm{a}}$ \\
\hline
\end{tabular}

Results shown as means \pm SD $(n=3)$. Data within rows followed by different letters are significantly different $(p<0.05)$. 
The color parameters, namely brightness $\left(L^{*}\right)$, redness-greenness $\left(a^{*}\right)$ and yellowness-blueness $\left(b^{*}\right)$, of dried edible bolete are illustrated at Figure $2 \mathrm{a}-\mathrm{c}$. The $\mathrm{L}^{*}, \mathrm{a}^{*}$ and $\mathrm{b}^{*}$ values of dried edible bolete decreased, particularly at high temperature. The color changes of the dried bolete were even more observed when the drying time was longer. According to Kotwaliwale et al. (2007), the color index of Pleuratus spp. was also significantly changed during drying with higher temperature and longer time.

The results of total phenol content and antioxidant activity by analyzing the ability to capture free radicals (DPPH) of dried edible bolete are shown in Figure 3a-b. It was found that these antioxidative properties of the dried mushroom drastically decreased when dried mushrooms at a higher temperature and a longer time. At $60^{\circ} \mathrm{C}$ for $5 \mathrm{~h}$, the amount of total phenol content and DPPH were significantly decreased from 64.3 to $16.7 \mathrm{GA} \mathrm{mg} / 100 \mathrm{~g}$ fresh samples and reduced from 37.9 to $9.3 \mathrm{GA} \mathrm{mg} / 100 \mathrm{~g}$ fresh samples, respectively $(\mathrm{p}<0.05)$. They decreased by about $75 \%$ compared to the fresh mushroom. The drying temperature is a very important variable in the mushroom drying, resulting in the changes in physicochemical and antioxidative properties. These results are in agreement with the results found by Choycharoen et al. (2016) that the cooking process had changed the properties of the active ingredient and the amount of antioxidant phenolic compounds in Shiitake, Eryngii and oyster mushrooms, and Auricularia auricula-judae (Bull.).

\subsection{Changes of dried edible bolete with different storage conditions}

The changes in $\mathrm{A}_{\mathrm{w}}$, moisture content and microbial count of dried edible bolete with and without vacuum packing at room temperature $\left(35 \pm 2{ }^{\circ} \mathrm{C}\right)$ were monitored for six months and the results show in Figure $4 \mathrm{a}-\mathrm{c}$. The $\mathrm{A}_{\mathrm{w}}$ and moisture content of both dried edible bolete packages were not statistically different $(p>0.05)$ with the average values of 0.634 and $14.2 \%$, respectively. However, the amount of microorganisms had a downward trend until the fourth month and all microbes tended to increase afterwards. It may be due to the inhabitation of microorganism growth without oxygen condition. After six months, the microbial count of dried edible bolete with vacuum packing was lower than that of without vacuum packing $\left(8 \times 10^{3}\right.$ and $4 \times 10^{4} \mathrm{CFU} / \mathrm{g}$,
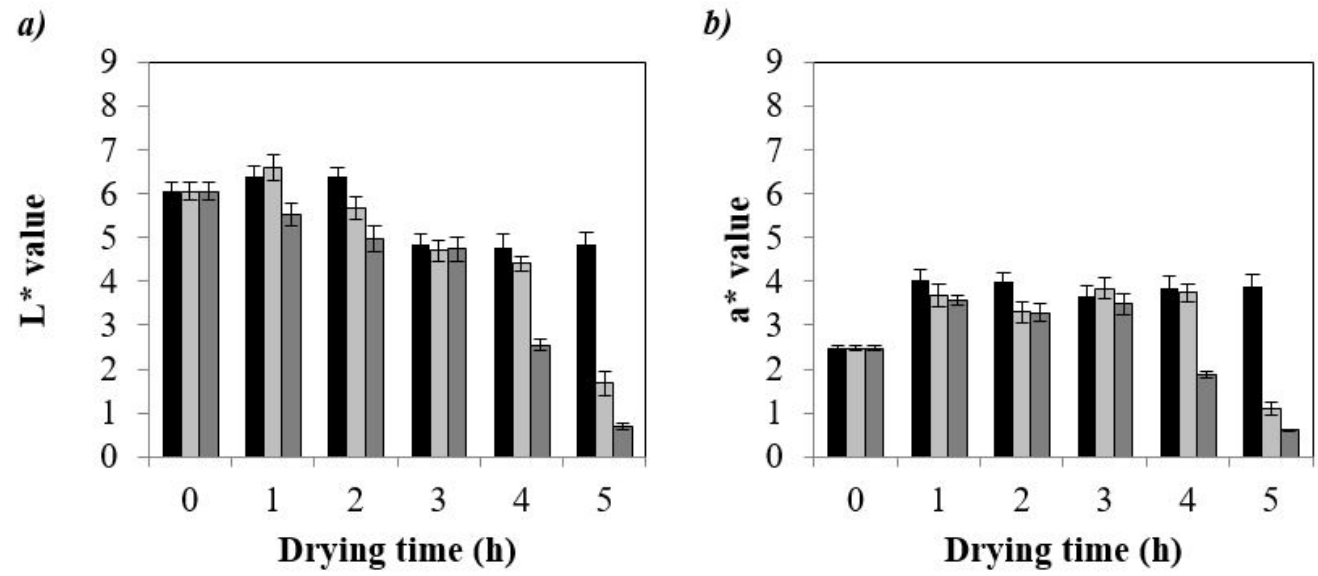

c)

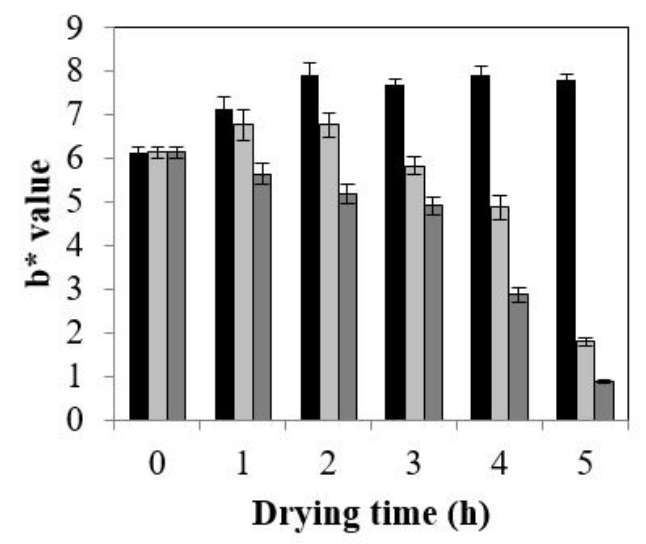

- $40^{\circ} \mathrm{C} \quad \square 50^{\circ} \mathrm{C} \quad \square 60^{\circ} \mathrm{C}$

Figure 2. Color parameters (a) brightness ( $L^{*}$ value), (b) redness-greenness ( $a^{*}$ value) and (c) yellowness-blueness $\left(b^{\star}\right.$ value) of dried bolete at various drying temperatures for $5 \mathrm{~h}$. 
a)

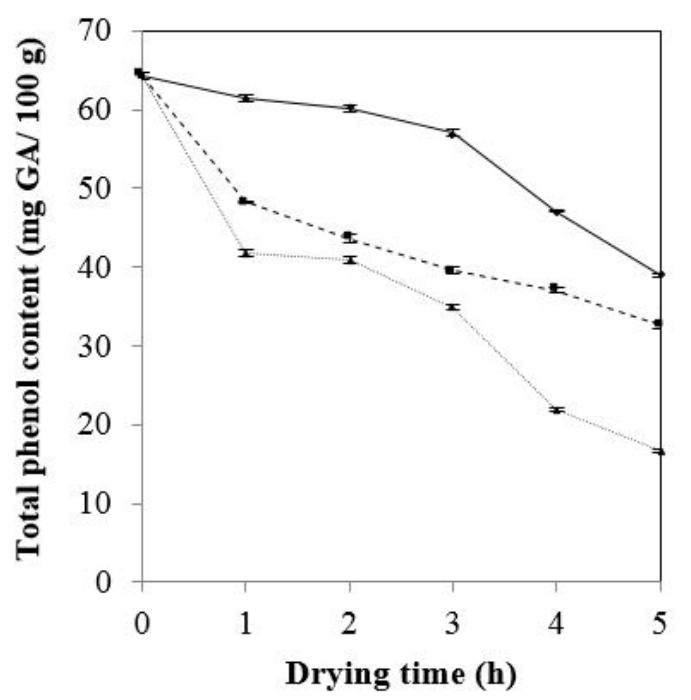

b)

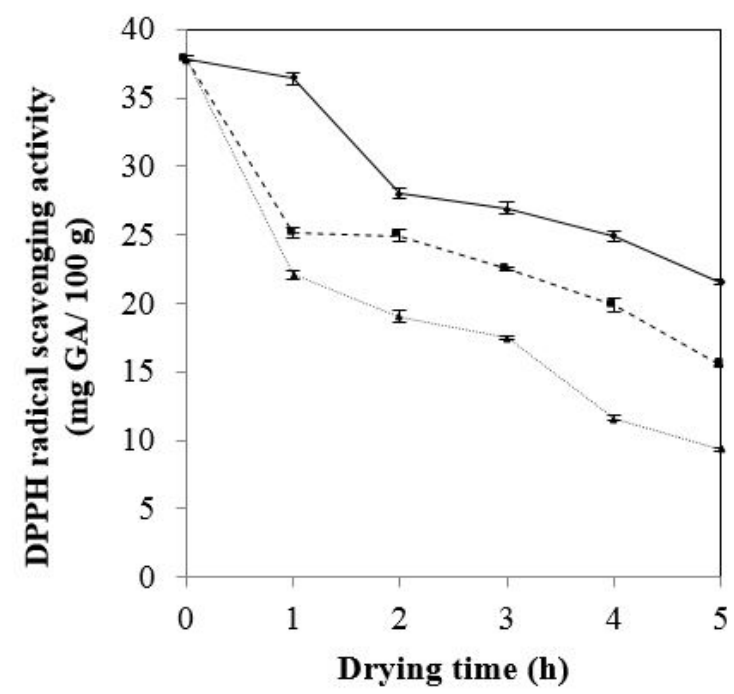

$\longrightarrow 40^{\circ} \mathrm{C} \quad-\cdots 50^{\circ} \mathrm{C} \quad \therefore 60^{\circ} \mathrm{C}$

Figure 3. Antioxidative properties of edible bolete dried at $40-60^{\circ} \mathrm{C}$ for $5 \mathrm{~h}$.

a)

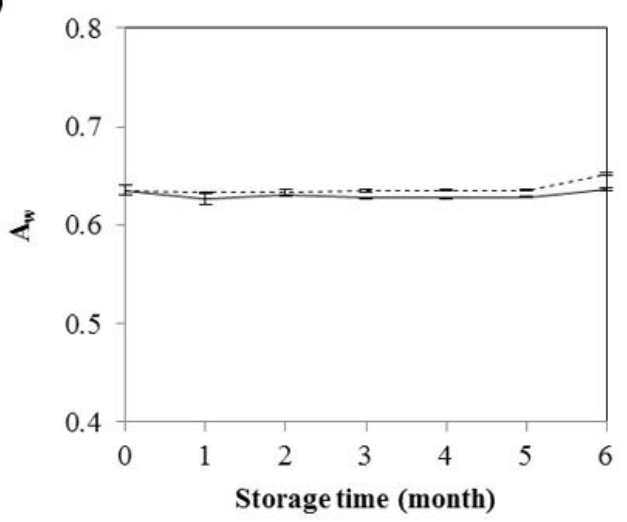

c)

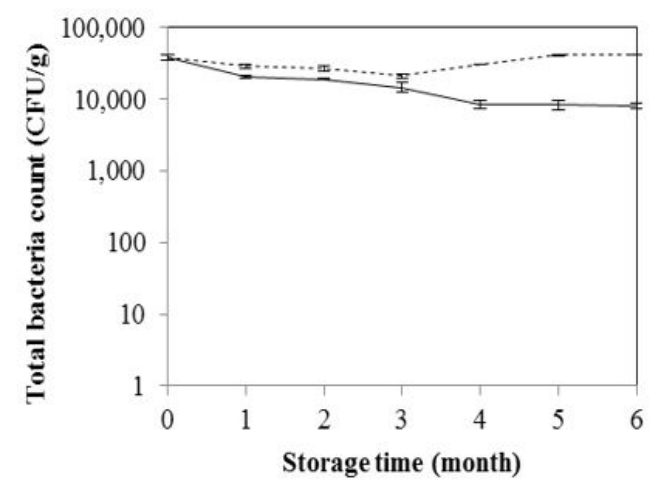

b)

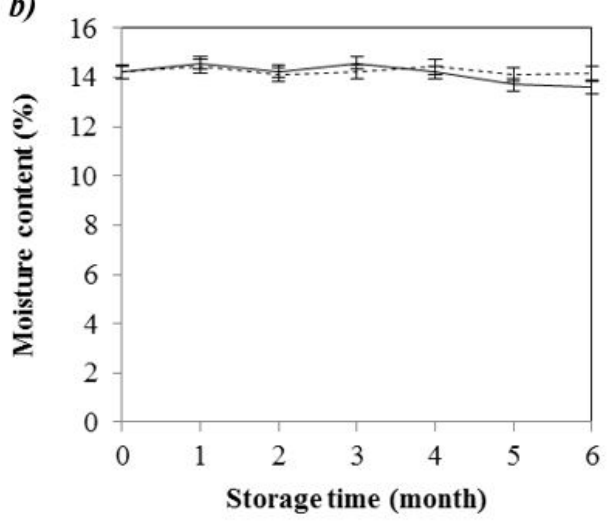

Figure 4. Changes of (a) $A_{w^{\prime}}$ (b) moisture content and (c) total bacteria count of dried bolete over 6 months at room temperature. 
respectively). In general, fresh mushrooms might be stored for few days due to its perishable nature. Therefore, the drying could be used to prolong shelf-life of the mushroom, and the dried mushroom is also recommended to apply for various food products in order to the value addition with improving nutritional value in the developed product (Singh et al., 2016).

\section{Conclusions}

According to the major finding results, the protein and fiber contents, and antioxidative properties of the edible bolete mushroom were highest among Shiitake, Eryngii and oyster mushrooms. The bolete mushroom, therefore, presented as a sufficient source of natural antioxidants. The changes in properties of dried edible bolete were observed as affected by drying temperature and time, particularly at high temperature and long time. After drying at $60^{\circ} \mathrm{C}$ for $5 \mathrm{~h}$, the total phenolics and antioxidative activity of dried edible bolete about one-fourth still remained. This study has provided a basis for further exploring the antioxidant components in edible bolete mushroom.

\section{Acknowledgements}

Supports by Rajamangala University of Technology Suvarnabhumi (RMUTSB), the Thailand Research Fund (TRF), and National Research Council of Thailand (NRCT) under research project No.RDG58A0002/08 are acknowledged. The manuscript was developed with the support by 24 : The best of both worlds Project.

\section{References}

Apati, G. P., Furlan, S. A., \& Laurindo, J. B. (2010). Drying and rehydration of oyster mushroom. Brazilian Archives of Biology and Technology, 53(4), 945-952. http://dx.doi.org/10.1590/S1516-89132010000400025.

Association of Official Analytical Chemists - AOAC. (1990). Official method of analysis (15th ed.). Arlington: AOAC.

Association of Official Analytical Chemists - AOAC. (1995). Official method of analysis (16th ed.). Arlington: AOAC.

Aung-aud-chariya, A., Bangrak, P., Dell, B., Lumyong, S., \& Kamlangdee, N. (2012). Preliminary molecular identification of Boletus griseipurpureus Corner from Thailand and its nutritional value. Journal of Agricultural Technology, 8(6), 1991-1998.

Cheung, L. M., Cheung, P. C. K., \& Ooi, V. E. C. (2003). Antioxidant activity and total phenolics of edible mushroom extracts. Food Chemistry, 81(2), 249-255. http://dx.doi.org/10.1016/S0308-8146(02)00419-3.

Choycharoen, P., Nonthawong, K., Dongjan, P., Teangsoan, K., Tubtimhom, W., Sinthupibunkit, C., Prathumwan, J., Rattanasinkunchan, P., \& Janwitthayanuchit, I. (2016). The effect of boiling on antioxidant activity of king oyster mushroom, jew's ear mushroom, phoenix oyster mushroom and shitake mushroom. In Proceedings of the 7th National and International Conference (Speed up Research towards World Class University), Bangkok, Thailand.

Elmastas, M., Isildak, O., Turkekul, I., \& Temur, N. (2007). Determination of antioxidant activity and antioxidant compounds in wild edible mushrooms. Journal of Food Composition and Analysis, 20(3-4), 337-345. http://dx.doi.org/10.1016/j.jfca.2006.07.003.

Ferreira, I. C. F. R., Barros, L., \& Abreu, R. M. V. (2009). Antioxidants in wild mushrooms. Current Medicinal Chemistry, 16(12), 1543-1560. PMid:19355906. http://dx.doi.org/10.2174/092986709787909587.
García-Pascual, P., Sanjuán, N., Bon, J., Carreres, J. E., \& Mulet, A. (2005). Rehydration process of Boletus edulis mushroom: characteristics and modeling. Journal of the Science of Food and Agriculture, 85(8), 1397-1404. http://dx.doi.org/10.1002/jsfa.2126.

Hawksworth, D. L., Kirk, P. M., Sutton, B. C., \& Pegler, D. N. (1995). Ainsworth and Bisby's dictionary of the fungi (8th ed.). Oxon, UK: $\mathrm{CAB}$ International.

Ignat, I., Volf, I., \& Popa, V. I. (2011). A critical review of methods for characterisation of polyphenolic compounds in fruits and vegetables. Food Chemistry, 126(4), 1821-1835. PMid:25213963. http://dx.doi. org/10.1016/j.foodchem.2010.12.026.

Kotwaliwale, N., Bakane, P., \& Verma, A. (2007). Changes in textural and optical properties of oyster mushroom during hot air drying. Journal of Food Engineering, 78, 1207-1211.

Kumar, R., Tapwal, A., Pandey, S., Borah, R. K., Borah, D., \& Borgohain, J. (2013). Macro-fungal diversity and nutrient content of some edible mushrooms of Nagaland, India. Nusantara Bioscience, 5(1), 1-7.

Lim, Y. Y., Lim, T. T., \& Tee, J. J. (2007). Antioxidant properties of several tropical fruits: A comparative study. Food Chemistry, 103(3), 10031008. http://dx.doi.org/10.1016/j.foodchem.2006.08.038.

Maestri, D. M., Nepote, V., Lamarque, A. L., \& Zygadlo, J. A. (2006). Natural products as antioxidants. In I. Filippo (Ed.), Recent advances in phytochemistry (pp. 105-135). Kerala, India: Research Signpost.

Mahattanatawee, K., Manthey, J. A., Luzio, G., Talcott, S. T., Goodner, K., \& Baldwin, E. A. (2006). Total antioxidant activity and fiber content of select Florida-grown tropical fruits. Journal of Agricultural and Food Chemistry, 54(19), 7355-7363. PMid:16968105. http://dx.doi. org/10.1021/jf060566s.

Rai, M., Tidke, G., \& Wasser, S. P. (2005). Therapeutic potential of mushrooms. Natural Product Radiance, 4, 246-257.

Sanmee, R., Dell, B., Lumyong, P., Izumori, K., \& Lumyong, S. (2003). Nutritive value of popular wild edible mushrooms from northern Thailand. Food Chemistry, 82(4), 527-532. http://dx.doi.org/10.1016/ S0308-8146(02)00595-2.

Sarikurkcu, C., Tepe, B., \& Yamac, M. (2008). Evaluation of the antioxidant activity of four edible mushrooms from the central Anatolia, Eskisehir-Turkey: Lactarius deterrimus, Suillus collitinus, Boletus edulis, Xerocomus chrysenteron. Bioresource Technology, 99(14), 6651-6655. PMid:18178083. http://dx.doi.org/10.1016/j. biortech.2007.11.062.

Seehanan, S., \& Petcharat, V. (2008). Some species of wild boletes in Thailand. Journal of Agricultural Technology, 4(1), 109-118.

Singh, J., Sindhu, S. C., Sindhu, A., \& Yadav, A. (2016). Development and evaluation of value added biscuits from dehydrated shiitake (Lentinus edodes) mushroom. International Journal of Current Research, 8(3), 27155-27159.

Tesoriere, L., Allegra, M., Gentile, C., \& Livrea, M. A. (2009). Betacyanins as phenol antioxidants: chemistry and mechanistic aspects of the lipoperoxyl radical-scavenging activity in solution and liposomes. Free Radical Research, 43(8), 706-717. PMid:19548153. http://dx.doi. org/10.1080/10715760903037681.

Tsai, S. Y., Tsai, H. L., \& Mau, J. L. (2007). Antioxidant properties of Agaricus blazei, Agrocybe cylindracea, and Boletus edulis. Lebensmittel-Wissenschaft + Technologie, 40(8), 1392-1402. http:// dx.doi.org/10.1016/j.lwt.2006.10.001.

Turkmen, N., Sari, F., \& Velioglu, Y. S. (2005). The effect of cooking methods on total phenolics and antioxidant activity of selected 
green vegetables. Food Chemistry, 93(4), 713-718. http://dx.doi. org/10.1016/j.foodchem.2004.12.038.

Vamanu, E., \& Nita, S. (2013). Antioxidant capacity and the correlation with major phenolic compounds, anthocyanin, and tocopherol content in various extracts from the wild edible Boletus edulis mushroom. BioMed Research International, 2013, 313905. PMid:23509707. http://dx.doi.org/10.1155/2013/313905.

Vidović, S. S., Mujić, I. O., Zeković, Z. P., Lepojević, Z. D., Tumbas, V. T., \& Mujić, A. I. (2010). Antioxidant properties of selected boletus mushrooms. Food Biophysics, 5(1), 49-58. http://dx.doi.org/10.1007/ s11483-009-9143-6.
Walde, S. G., Velu, V., Jyothirmayi, T., \& Math, R. G. (2006). Effects of pretreatments and drying methods on dehydration of mushroom. Journal of Food Engineering, 74(1), 108-115. http://dx.doi.org/10.1016/j. jfoodeng.2005.02.008.

Wu, L. C., Hsu, H. W., Chen, Y. C., Chiu, C. C., Lin, Y. I., \& Ho, J. A. A. (2006). Antioxidant and antiproliferative activities of red pitaya. Food Chemistry, 95(2), 319-327. http://dx.doi.org/10.1016/j. foodchem.2005.01.002.

Yapar, S., Helvaci, S. S., \& Peker, S. (1990). Drying behavior of mushroom slices. Drying Technology, 8(8), 77-79. http://dx.doi. org/10.1080/07373939008959865. 